\title{
Production of fuel gases from reed by using downdraft gasifier
}

\author{
Abdul-Hameed Al-Obaidy ${ }^{1}$, Riyad Al-Anbari ${ }^{2}$, Hussein Kazim ${ }^{2} *$ \\ ${ }^{1}$ Environmental Research Center, University of Technology, Baghdad, Iraq, \\ ${ }^{2}$ Department of Building and Construction Engineering, University of Technology, Baghdad, Iraq
}

\begin{abstract}
This study was conducted to investigate the ability of reed as a Production of gases via gasification technique by using special gasifier made for this purpose and to evaluate the produced gases $\left(\mathrm{CO}, \mathrm{H}_{2}, \mathrm{CO}_{2}\right.$ and $\mathrm{CH}_{4}$ ). The results showed that the percentage of production gases was $15.6 \%, 10.2 \%, 7.81 \%$ and $1.69 \%$ for carbon monoxide, carbon dioxide, hydrogen and methane respectively. In addition, it showed that the highest temperature up to the gasifier was $700^{\circ} \mathrm{C}$ and the time required to complete gasification process was $23 \mathrm{~min}$. The results indicated that $5 \mathrm{~kg}$ of reed was capable of producing $10 \mathrm{~m} 3$ of gases which produces about $1 \mathrm{HP}-\mathrm{hr}$. that equivalent to $3.75 \mathrm{kWh}$.
\end{abstract}

\section{Introduction}

Reeds are found all over the world except Antarctica, but there are many area in Europe, the Middle East and America [1], and the reed is called either 'first generation or second generation.. The first generation is when be source of biomass from food crop (e.g maize) and the second generation is when the source of biomass from non-food crops (e.g reed).[2] There are three ways to use the reed as a source of energy which are combustion or gasification, biogas and biofuel.[3]

There are two ways to convert solid waste into fuel; where the first method is biochemical, which is achieved by the decomposition of organic matter by organisms. The disadvantages of this method are the requiring expensive enzymes, a large amount of feed preconditioning, and producing a single product (e.g. ethanol) $[4,5]$. The second way is to convert solid waste into fuel by thermochemical; this method is carried happening by heating the biomass in the presence of steam, oxygen or air to a temperature between 500 and $850^{\circ} \mathrm{C}$. This method is called gasification in case oxygen presence or pyrolysis in the absence of oxygen .High temperature allows breaking of the cellulosic material into a mixture of gases mainly hydrogen and carbon monoxide known as synthesis gas ("syngas").

Gasification is usually defined as the conversion of carbon into gases produced by partial oxidation. The resulting gas is known as syngas, which contains hydrogen and carbon monoxide mainly, as well as methane and carbon dioxide. This gas is later used in more than one field after passing through many processes [6]. Coal is the first material used in the process of gasification but due to demand of sustaining the earth resources, other types of feedstock are being used; which include reeds, corn residues and sawdust...etc. [7].Chemical reaction in the gasification process where some of which are exothermic and some are endothermic [8]. The main advantages of this technique are the low cost of waste used in addition to recycle this waste. Gasification is similar to combustion, but it is considered as partial combustion process, and it has smaller carbon dioxide (greenhouse gas) emission [9].

\section{Materials and methods}

\subsection{The gasifier model: Overview and Specifications}

The gasifier GEK system (version 4) was constructed from ALL Power Labs Company, and given to the University of Technology by the US Embassy in Baghdad then building in Ministry of Science and Technology, Baghdad, Iraq.. It is essential to work on all the required specifications for gasification systems as shown in Table 1. The GEK Systems are designed for raw biomass and organic-based feedstock's. Experimental feedstock's lying outside of the suggested ranges may require modification of the equipment and testing of the gas quality produced.

\footnotetext{
*Corresponding Author: Hussein.a.kazim@gmail.com
} 
The capacity of gases produced by this model is about 2 $\mathrm{m} 2$ per $1 \mathrm{~kg}$ biomass which produces about $0.75 \mathrm{kWh}$ with biomass consumption rate $(\mathrm{kg} / \mathrm{hr}$.) about $12 \mathrm{~kg}$. Dimension of this model is $61 \mathrm{~cm}$ height and $43 \mathrm{~cm}$ diameter.

Table 1: Solid waste requirement

\begin{tabular}{|c|c|}
\hline Size of particle (in) & $5-1.5$ \\
\hline Content of moisture (\% by dry weight) & Less than 25 \\
\hline Fixed to volatile ratio & More than 0.25 \\
\hline Content of ash (\%) & More than 5 \\
\hline
\end{tabular}

\subsection{Preparation of feedstock}

Feedstock selection and preparation are the most important variable toward successful operation of gasifier. Biomass fuel does not come in standard forms. Shape, size, moisture levels and mineral contents vary greatly. Understanding the impacts of these variables on gasifier operation, and preparing fuel accordingly, are most important assignment for operating gasifier model. Fresh reed was harvested from the Tigris river in Baghdad at Al-Kadhemia section, the reed samples were dried by sun light for 5 days to obtain moisture content required for gasification process (15-20\% is usually ideal) then used as feedstock to gasifier operation, High moisture content leads to reduce the temperature in the combustion zone and thus not to get a process of gasification completed [10]. After drying process, the reed was milling into small particles using blender $0.5-1.5$ in, where larger particles can form bridges which avoid the feed moving down, while smaller particles lead to block the available air void age, leading to shutdown of the gasifier [11].The physical and chemical properties were measured at the Ministry of Science and Technology according to the standard method ASTM. Figure 1 shows the steps followed in the process of gasification. After the process of harvested reeds, the preparation of raw materials through drying and reduce the size to the specifications required in addition to the procedure of preliminary tests, such as moisture content, density and size. The second step is to transfer the raw materials to the gasifier and then to measure the internal and external temperature as well as the gases produced by sensors prepared for this purpose.

\subsection{Operation of gasifier}

As shown in Figure 2, after the process of sizing and drying, the raw material was transferred to the reactor through a hole located at the top of the gasifier, and after filling reactor with raw material, the compressor was connected to the reactor through a controlled pipe. Then we burn the reeds by torch with insert a small amount of crude oil to accelerate the ignition, after few minutes.. The hot gas exits the reactor and passes through both a cyclone and filter to separate char particulates. The temperature and concentration of gas measured by sensors proposed to this purpose.

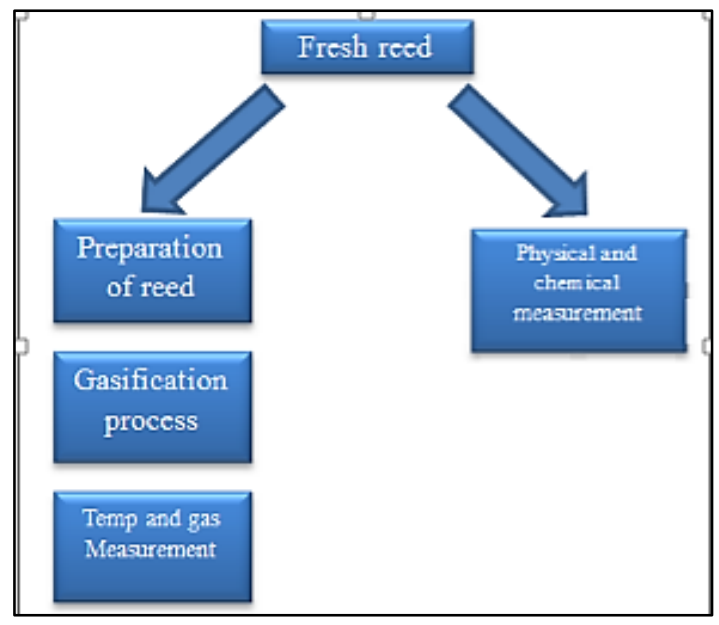

Figure 1: The route of gasification process

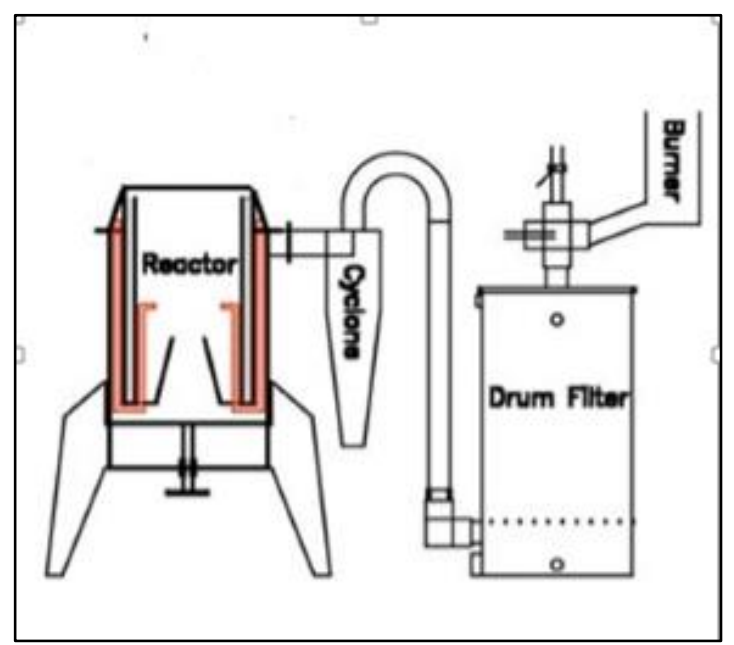

Figure 2: Diagram of downdraft gasifier

\section{Results}

The physical and chemical properties were measurement before gasification process, table below shows properties of reed. 
Table 2: Analysis of physical and chemical the reed used [Ü. Kask]

\begin{tabular}{|c|c|}
\hline Moisture content (dry basis \%) & 17 \\
\hline Ash content (\%) & 6.5 \\
\hline $\mathrm{CV}(\mathrm{MJ} / \mathrm{kg})$ & 18.5 \\
\hline $\mathrm{C}$ & 46.5 \\
\hline $\mathrm{H}$ & 6.2 \\
\hline $\mathrm{O}$ & 40.7 \\
\hline
\end{tabular}

The following figure shows that the chemical composite of the gas produced from reeds versus the reactor temperature, where it shows percentage of gases $(\mathrm{CO}$, $\mathrm{CO} 2, \mathrm{H}_{2}$ and $\mathrm{CH} 4$ ) at a temperature up to $700^{\circ} \mathrm{C}$.

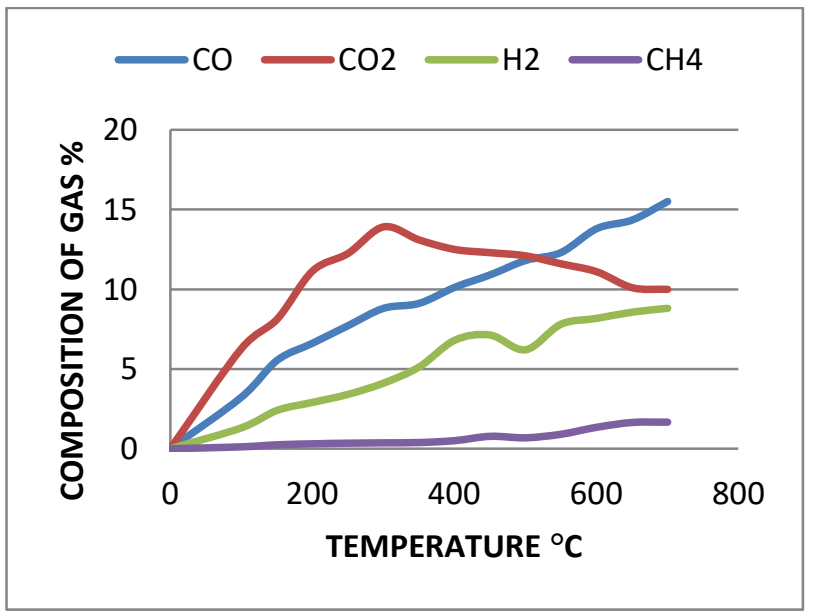

Figure 3: Effect of temperature ${ }^{\circ} \mathrm{C}$ on chemical compounds of gas produced from reeds $(\%)$

Lower heating value (the amount of heat released during the combustion of a specified amount of it) was calculated based on the resulting of gas compounds and according to the following equation [Reza A. Moghadom]: LHV $(\mathrm{MJ} / \mathrm{M} 3)=$ $(107.98 * \mathrm{H} 2+126.36 * \mathrm{CO}+358.18 * \mathrm{CH} 4+56 * \mathrm{C} 2 \mathrm{H} 2) / 1000$.

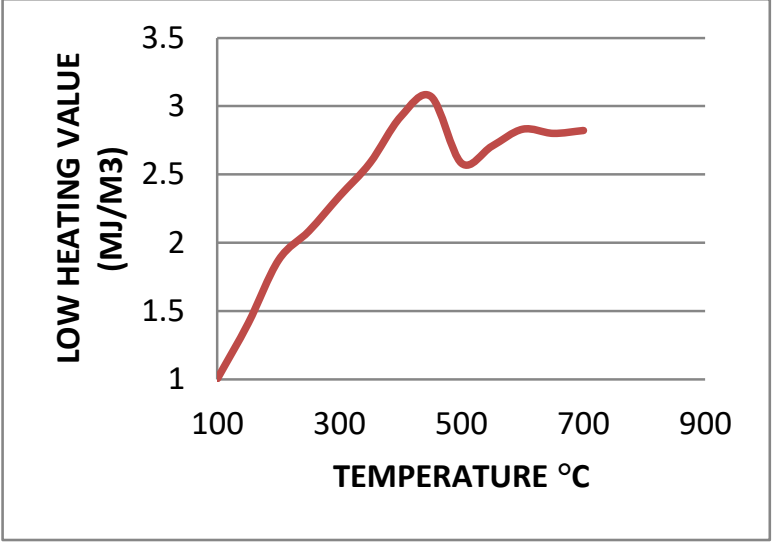

Figure 4: The relationship between heat values (MJ/M3) with temperature ${ }^{\circ} \mathrm{C}$

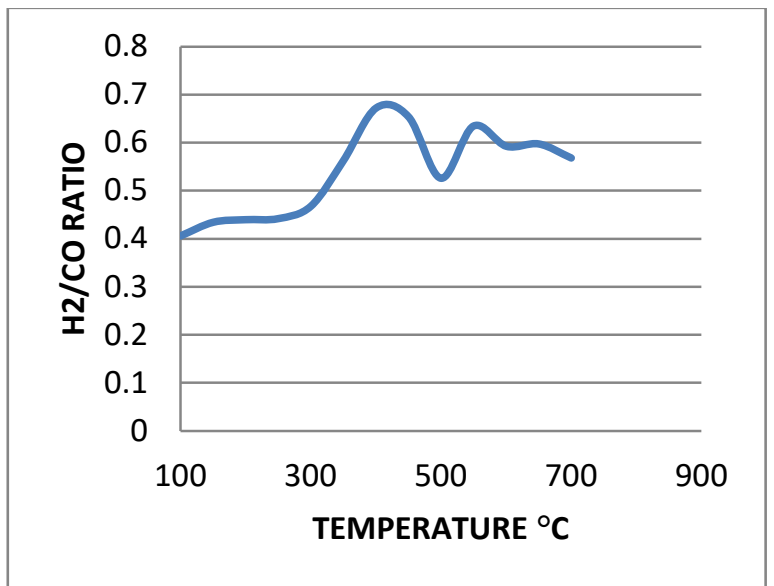

Figure 5: $\mathrm{H}_{2}: \mathrm{CO}$ ratio of fuel gas production as function of reactor temperature ${ }^{\circ} \mathbf{C}$

Figure 6 illustrates the relationship between the chemical compounds of the yield gas and the rate of consumption of solid waste. Where it was noted that the time of consumption of solid waste is 23 minutes.

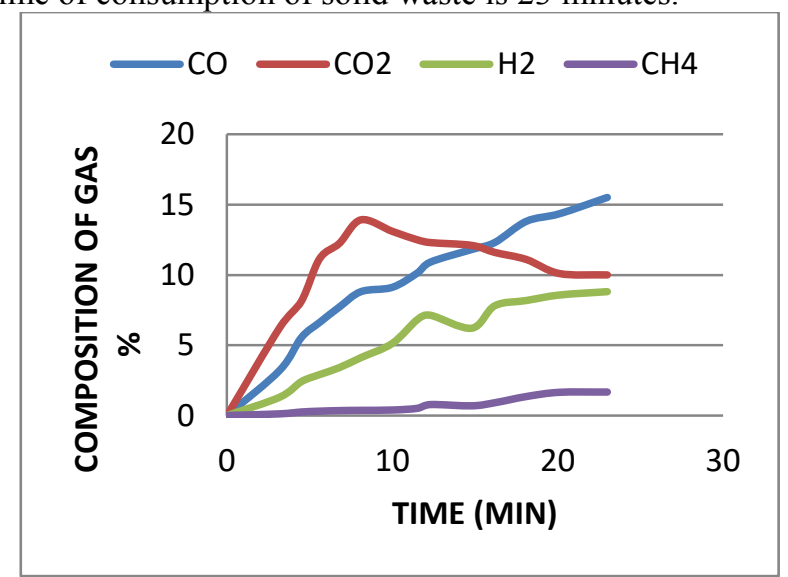

Figure 6: Variation of gasification output with operation time (min) 
The Figure (5) shows the relationship between the reactor temperature and the time required to consumption the reed, this figure also illustrates the thermal behavior of reed used as raw material to gasification process.

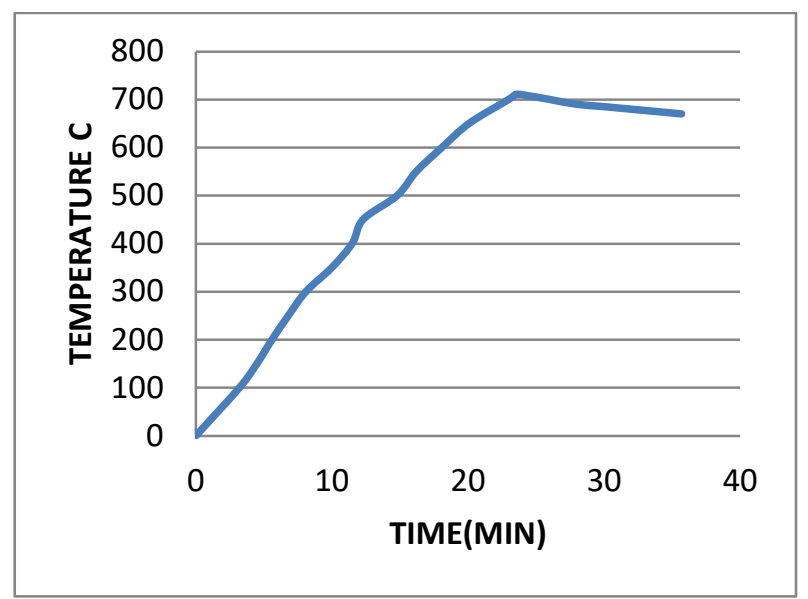

Figure 7: Thermal behavior of reed with operation time (min)

Table 3: The results of the experimental gasification

\begin{tabular}{|c|c|c|c|c|}
\hline Characterizes & Min & Max & Average & STD \\
\hline Temp ${ }^{\circ} \mathrm{C}$ & 100 & 710.6 & 493.26 & \pm 2120.29 \\
\hline $\mathrm{CO} \%$ & 3.23 & 15.6 & 9.99 & \pm 3.63 \\
\hline $\mathrm{CO} 2 \%$ & 6.27 & 10.5 & 9.10 & \pm 1.04 \\
\hline $\mathrm{H}_{2} \%$ & 1.31 & 7.81 & 5.39 & \pm 2.3 \\
\hline $\mathrm{CH}_{4} \%$ & 0.12 & 1.67 & 0.71 & \pm 0.52 \\
\hline $\mathrm{LHV}(\mathrm{MJ} / \mathrm{M} 3)$ & 1 & 2.53 & 2 & \pm 0.54 \\
\hline
\end{tabular}

\section{Discussion}

From the results shown in Figure 3, the highest produced gas was $\mathrm{CO}$ with percentage of $15.6 \%$ at $700.4^{\circ} \mathrm{C}$, followed by carbon dioxide with content of $10.5 \%$ at $300.5^{\circ} \mathrm{C}$, then hydrogen and methane with $7.81 \%$ and $1.67 \%$ at $550.2^{\circ} \mathrm{C}$, $700.4^{\circ} \mathrm{C}$ respectively. The high percentage of $\mathrm{CO}$ gas was due to the high carbon content found in the reed as shown in Table 2.

It was also observed that carbon monoxide and hydrogen were rapidly increased with increasing temperature through reaction (6 and 7)[lv et 2004] while carbon dioxide was decreased at $300.5{ }^{\circ} \mathrm{C}$. Methane was found to have increased slowly as the temperature increased.

Figure 4 shows an increase in the value of LHV with increasing temperature due to the increase of concentration of CO in syngas [Moni et 2012], where LHV depends on the flammable gases and then decrease it at a temperature of $450^{\circ} \mathrm{C}$ because of the apparent increase of both hydrogen gas and methane compared to slightly increase of gas.

As for Figure 5, it was found that the highest value of $\mathrm{H} 2$ : $\mathrm{CO}$ at $450{ }^{\circ} \mathrm{C}$ temperature due to the increase of hydrogen gas compared to $\mathrm{CO}$. the increase concentration of $\mathrm{CO}$ compared to decreasing amount of $\mathrm{H}_{2}$ with increased temperature caused decreasing in $\mathrm{H} 2: \mathrm{CO}$ ratio[Moni et 2012]

The study of the effect of time on the concentration of gas produced is to know the maximum operating time until the gasifier needs to stop the supply syngas. Figure 6 shows that the highest value was for gas $\mathrm{CO}$ at a time of 23 minutes after steady climb and then experiencing a drop towards the end of operation. Also for $\mathrm{H} 2$ showed almost the same pattern.

Increasing the temperature of the reed regularly indicates the efficiency of the gasifier system as illustrated in Figure 7 Also the highest value heart temperature (T1) is approximately $700.3{ }^{\circ} \mathrm{C}$ at 23 minutes. The heart temperature stabilized at $600{ }^{\circ} \mathrm{C}$ due to depletion of the batch of fuel fed to reactor.[17]

The thermodynamic changes during the gasification process are due to the chemical reaction obtained within the gasifier. Increased temperature for reed is the result of energy released from exothermic the reactions as show below [14]

\begin{tabular}{|c|}
\hline Reactions \\
\hline $2 \mathrm{C}+\mathrm{O} 2=2 \mathrm{CO}$ partial oxidation (1) \\
\hline $\mathrm{C}+\mathrm{O} 2=\mathrm{CO} 2$ complete oxidation, (2) \\
\hline $\mathrm{C}+2 \mathrm{H} 2=\mathrm{CH} 4$ (hydro-gasification/methanation \\
reaction), (3) \\
\hline $\mathrm{CO}+\mathrm{H} 2 \mathrm{O}=\mathrm{CO} 2+\mathrm{H} 2$ water-gas shift reaction,(4) \\
\hline $\mathrm{CH} 4+\mathrm{H} 2 \mathrm{O}=\mathrm{CO}+3 \mathrm{H} 2$ steam reforming reaction, \\
$(5+\mathrm{H} 2 \mathrm{O}=\mathrm{CO}+\mathrm{H} 2$ water gas reaction, (6) \\
\hline $\mathrm{C}+\mathrm{CO} 2=2 \mathrm{CO}$ bounded reaction $(7)$ \\
\hline
\end{tabular}

\section{Conclusions}

The reed is found at high quantities in Iraq especially in the south area, this paper has dealt with the reed plant and tested by using gasification technology to assess how much energy can be produced from them. From the these results, it is clear that reeds have the ability to produce gas by gasification technique and the higher gas obtained was $\mathrm{CO}$ 
then $\mathrm{CO} 2, \mathrm{H} 2$ and $\mathrm{CH} 4$ respectively, This is due to chemical composition and thermal behavior of reed. As well $5 \mathrm{~kg}$ of reed used as raw material in this paper is capable of producing $10 \mathrm{~m} 3$ of combustible gases which equivalent about $3.75 \mathrm{kWh}$

\section{References}

1. S.M. Haslam "A Book of Reed: (Phragmitesaustralis (Cav.) Trin. ex Steudel, Formerly Phragmites communis Trin.)," Cardigan, GB: Forrest Text, pp 254, 1993.

2. J.F Kobbing, N. Thevs and S. Zerbe "The utilisation of reed (Phragmitesaustralis)," Mires and peat. Vol.13, pp.1-14, 2013.

3. Ecology Land and People (ELP) and N. Ash, "New Opportunities for the Sustainable Management of Fens: Reed Pelleting, Composting and the Productive Use of Fen Harvests," in Ecology, Land and People (ELP) for the Broads Authority, Norwich, UK, pp.66, 2010.

4. L.R. Lynd, J.H. Cushman, R.J. Nichols and C.E. Wyman "Fuel Ethanol from Cellulosic Biomass," Science, 251, 4999, 1318-1323, 1991.

5. Lynd, L.R., W.H. van Zyl, J.E. McBride and M. Laser "Consolidated Bioprocessing of Cellulosic Biomass: An Update. Current Opinion in Biotechnology," Curr Opin Biotechnol., 16, 5, 577-83, 2005.

6. Gasification Technologies Council "Gasification: Redefining Clean Energy," available online: http://www.gasification.org/ [accessed Oct 2010]

7. M.R. Bricka, D.C. Swalm "Energy Crop Gasification and Gasification Issues," School of Chemical Engineering Mississippi State University.

8. C. Higman, M. van der Burgt, "Gasification," Gulf Professional Publishing, Second edition, 12-15, 33-36, 2008.

9. L. Zhang, C. (Charles) $\mathrm{Xu}$, and P. Champagne "Overview of Recent Advances in Thermo-Chemical
Conversion of Biomass," Energy Conversion and Management, 51, 969-982, 2010.

10. W. Simpson and A. Tenwolde, "Physical Properties and Moisture Relations of Wood," in Wood Handbook: Wood as an Engineering Material. Madison, WI: USDA Forest Service, Forest Products Laboratory, 1999. General technical report FPL; GTR-113, pp 3.13.24, 1999.

11. P. McKendry, "Energy Production from Biomass (Part3): Gasification Technologies, " Bioresource Technology, 83, 1, 55-63, 2002.

12. Ü. Kask, L. Kask and S. Link, "Combustion characteristics of reed and its suitability as a boiler fuel" Mires and Peat, Volume 13 (2013/14)

13. G. Xian Sheng," Biomass Gasifiers: From Waste to Energy Production" Biomass 20 (1989) 3-12 14. J. F. V'elez, F. Chejne, C. F. Vald'es, E. J. Emery, and C. A. Londõno, "Cogasification of Colombian coal and biomass in fluidized bed: an experimental study," Fuel, vol. 88, no. 3, pp. 424-430, 2009

15. R.Moghdam, S.Yusup, W.Azlin, S.Nehzati, A.Tavasoli,'Investigation on syngas production via biomass conversion through the integration of pyrolysis and air-steam gasification processes' 'Energy Conversion and Management, Volume 87, November 2014, Pages 670-675

16. M.N.Z.Moni,S.A.Sulaiman "Downdraft Gasification of Oil Palm Frond, "journal of applied science 12(24):2547-2579.2012

17. Samson mikbeb antaw'study on tar generated from downdraft gasification of oil palm fronds ' the scientist world journal, volume 2014 